УДК 130.2:128.5

DOI https://doi.org/10.32837/apfs.v0i27.922

\author{
О. Д. Яиенко \\ ORCID ID: https://orcid.org/0000-0003-0584-933X \\ кандидат філософських наук, доцент, \\ доцент кафедри методології науки та міжнародної освіти \\ Національного педагогічного університету імені М. П. Драгоманова
}

\title{
ФЕНОМЕНОЛОГІЯ ТА МЕТАФІЗИКА КУЛЬТУРИ М. ГАЙДЕГГЕРА
}

Постановка проблеми. Феноменологія як метод філософського дослідження має метою делегітимізацію необгрунтованих абстракцій. Прагнучи уникнути диктатури абстракції, Е. Гуссерль вводить поняття «стабільних очевидностей». Монументальність культури втілюється в очевидних формах предметної або ідейної цілісності. Саме тому класичні абстракції дефініцій культури трансформуються у феноменології в якісно змістовне поняття Життєвого світу. Дегуманізація культури в цілому і науки зокрема, абсолютизація гносеологічних процедур взаємодії з дійсністю, формалізація світоглядних принципів аксіології - всі ці радикальні установки традиційного філософствування призвели до дезорієнтації особистості, відчуження та забуття. Феноменологія прагне обгрунтувати «живе тіло» культури в єдності їі універсалій та варіацій емпірики. За умови такого підходу поняття культури набуває необхідної модальної векторності, потенціалу динаміки та змін відповідно до логіки самого життя. Якщо ж аналізувати не проективні можливості культури, а генезисні, то відповідно з феноменологічним дискурсом, історичний контекст буття культури формує нормативний досвід реалізації інтенціональних актів аналітики предметності. Таким чином, проблема культури не втратила свого глобального значення, але набула необхідного конкретного виміру та змісту в горизонті персонального екзистенційного досвіду. Існує думка, що гуссерліанський поворот у філоcoфiї $є$, насамперед, методологічним поворотом до людської сутності культури, персоналізованої та аксіоматичної. Отже, основним поняттям феноменології культури Е. Гуссерля є конституювання як інструмент упорядкування та організації трансцендентальним суб'єктом як світу природи, так і світу ідеальних сутностей, світу культури. Відповідно з такою логікою навколишній світ (Umwelt) не дається суб'єкту безпосередньо, а виключно крізь призму ментальних конструкцій акумульованого історичного досвіду, тобто культури. Тому первинною данністю взаємодії суб'єкта з реальністю є Життєвий світ (Lebenswelt), який поєднує хаотичність сприйняття із конституціями інтенціональної активності. Відповідно, рушієм людської активності проголошено навіть не при- родну каузальність та доцільність, а мотивацію як механізм цілепокладання та онтології цінності. Проголошуючи відмову від психологізму в філоcoфiï, автор активно впроваджує у філософський дискурс поняття установки. Диференціація натуралістичної та персональної установки передбачає їхню нівеляцію в установці феноменологічній, або «різниці різниці» («difference in difference»), функцією якої є виявлення транзитивності акцентів сприйняття та розуміння феноменів у повсякденному досвіді. Наслідком такої транзитивності $€$ відома теза Е. Гуссерля про сучасний кризовий стан культури. Гегемонія методу природничих наук формує спотворений образ як світу реального, так і світу ментального. У такому нарративі зміст культурних предикацій набуває ознак надлишковості та сумнівності. Саме такий висновок у логіці впровадження феноменологічного методу обурює видатного послідовника - М. Гайдеггера. Проте зауваження щодо карколомності цього філософського розриву є швидше перебільшенням.

Аналіз останніх досліджень і публікацій. Проблема кореляції феноменології, метафізики та фундаментальної онтології у визначенні сутності культури М. Гайдеггером не дає можливості однозначної відповіді. Так, С. Овергард [1] вивчає критику феноменологічного методу Гуссерля Гайдеггером у його ранніх лекціях. Але в ході герменевтичного розбору тексту автор приходить до висновку, що така критика методології $€$ внутрішньою, а не критикою спростування. Весь критичний пафос Гайдеггера не є стратегією анігіляції, або руйнування. Навпаки, філософія Гайдеггера, або фундаментальна онтологія, включає в себе критичний дискурс як складову практики інтерпретації. Тому критика у Гайдегера не означає спростування, а інший спосіб про-читання, розуміння та ви-значення. Таку позицію поділяють К. де Боер та С. Ховард [2], які переконують, що критика Гайдеггером кантіанської метафізики не тільки не оригінальна, але й демонструє спробу іï маргіналізації. На їхню думку, зосередженість Гайдеггера на поняттях основи та обгрунтування не дозволяє йому пояснити критику метафізичної традиції. Відповідь проста: у автора інша мета. Будь-який проект інтерпретації та розуміння Буття та Сущого має локальний вимір своєї придат- 
ності, тому будь-яка догма метафізики, релігії, політики тощо є згубною та небезпечною у своїх наслідках. Обгрунтування цієї тези полягає в диференціації світогляду, науки та філософії як окремих та специфічних активностей. Так, Карілемла С. [3] наполягає, що Гайдеггер відрізняє філософію як від світогляду, так і від науки. Авторка наводить історичну основу поняття світогляду у способі філософського мислення Гайдеггера. Для Гайдеггера світогляд - це умовний еквівалент, за допомогою якого сучасний суб’єкт уявляє себе та світ, з яким взаємодіє. Цю різницю доречно пояснити різними режимами темпоральності: світогляд є пластичною та рухомою структурою взаємодії суб’єктивності зі світом, горизонтом актуалізованого теперішнього; наука, навпаки, продукує та транслює сталі та об'єктивовані форми визначення, отже, є актуалізацією минулого у майбутнє; філософія є свого роду передбаченням, цілепокладанням (або буттям-до-смерті), тобто актуалізацією та проектуванням майбутнього в модусі теперішнього. Така стереоскопічна цілісність сприйняття світу характерна філософському методу Гайдеггера. Відповідно, Т. Мойл [4] специфіку філософського методу Гайдеггера вбачає у прагненні спіймати реалістичні імпульси природної свідомості, але без догмату метафізичного реалізму. Автор називає його методом трансцендентального емпіризму. Відповідно з такою установкою відносин людини та світу, свідомості та речі є паритетними, живими та справжніми. I якщо бути послідовними, то феноменологічний метод Гуссерля має ту саму мету та установку. Доречно зауважує Л. Hi [5], який вважає, що антиісторизм філософської думки Гуссерля є удаваним. Уся філософія Гуссерля є прагненням осмислення «поздовжньої інтенціональності історії часу-походження» , або з' ясування історико-культурної ретроспективи формування у свідомості інтенціональних матриць. Відповідно, ті протиріччя, що виникають у Гуссерля та Гайдеггера, не слід вважати драматичними або фатальними. На думку Ф. Касаті [6], основне питання фундаментальної онтології Гайдеггера призводить до протиріччя. Таку оцінку не слід вважати негативною, навпаки, відповідно до окремих концепцій аналітичної філософії протиріччя є продуктивним методом діалектизму - метафізичної позиції, що визнає протиріччя вірною відповіддю на фундаментальні питання.

Конкретна проблематика також складно піддається догматам універсалізму. Так, К. Нельсен [7] залучає філософію Гайдеггера для обгрунтування змісту практичного навчання. На відміну від інтелектуалістського підходу, Гайдеггер говорить про навчання як дієвість із предметами та інструментами, обладнанням. У такому розумінні не тільки формується певна майстерність виконання, але й знайомство із «підручністю» речей. Іншими словами, феноменологія Гайдеггера прагне відійти від протиріччя дедуктивно-індуктивних опозицій. Його деструкція має метою реанімацію іншого способу буття людини, який не обмежується схематизмом дистинкцій раціональності. У цьому контексті Р. Вінклер [8] на основі гайдегерівської філософії актуалізує тези про нормативність живої природи, а не фізичний порядок світу, про бідність буття людини у відношенні до тваринного світу та інтерпретацію людського способу буття як привласнення (Weltbildung).

Виклад основного матеріалу. М. Гайдеггер нівелює традиційне протиріччя природи та культури. Його фундаментальна онтологія є прагненням поєднати умовно роз'єднане, хаотичне та фрагментарне існування в єдину структурно-процесуальну організацію. Саме тому його філософія є відповіддю на глобальне питання про сутність Буття, або "реанімацію» Буття в семіотичних лабіринтах сучасної цивілізації. Свобода як фундаментальний екзистенціал людського існування продукує широкий спектр варіабельності запитів до світу. Відповідно, культура формує певну установку, виходячи з якої, людина запитує про суще як інтенціонально визначену єдність. Культура в широкому значенні, і наука як найвища форма раціоналізації, формують семантику і синтаксис способів запитування. А саме: «Наука взагалі може бути визначена як ціле обгрунтування зв'язку речей... Наука розуміє спосіб буття цього сущого (людини) як відношення людини. Це суще ми розуміємо термінологічно як існування... Існування є суще... Суще розуміється певним чином і визначене у своєму бутті... Розуміння буття є самовизначеністю буття існування. Оптичне існування буття полягає в тому, що воно є онтологічним... Саме буття, до якого існування може так або інакше відноситись і завжди містить таке відношення, ми називаємо екзистенцією... Існування розуміє себе самого завжди зі своєї екзистенції як певну можливість самого себе, бути самим собою або не бути таким» [9, с. 12]. Тобто цінність феноменологічного методу полягає в дослідженні такого фокусу сприйняття-оцінки сущого, що дозволяє долати стереотипність та автоматизм взаємодії зі світом, проникати до сутності речей та явищ.

Показово, що областю існування-формування сенсу Гайдеггер називає темпоральність. Саме темпоральність, адже час в його філософії - не фізична величина, а історична: «Існування «€» його минуле в способі його Буття» [9, с. 20]. Іншими словами, сенс сущого визначається в горизонті його межі існування та історичної ретроспективи становлення. Проблема простору є у Гайдеггера проблемою маркування, локалізацією змісту відповідно до обмежень та відмежувань. Переживання близькості та далечі є тими установками, які 
переформатовують контекст екзистенціальної турботи, «виривають» суще із потоку буденності та руйнують стереотипні інтенціональні конструкції. Таким чином, актуалізується можливість диференціації справжньої сутності сущого від уявної. Так само як межі існування, народження та смерть, локалізують сенс окремої персоніфікованої екзистенції. Спростовуючи традиційну суб'єкт-об'єктну метафізику із її постулатами наочності та вираженої предметності, приматом абстракції та категоріальності мислення, Гайдеггер радикально змінює акценти. Істина онтологічна, принципово не може бути об’єктивною, адже в такому випадку вона індиферентна; простір не може бути визначений як ємність предметності, іiі метрика, адже його зміст детермінований установкою, фокусом запитування; а сама установка запитів до світу є квінтесенцією історичного часу, безумовно, особистісного.

Гайдеггер скептично ставиться до відчуженого соціального, або об’єктивованого. Так, Ш. Кноулс [10] наполягає, що протиріччя у з'ясуванні значення між його ствердженням та створенням $€$ недоречним. Продовжуючи думку Гайдеггера, авторка зазначає, що значення обов'язково створюється та приймається одночасно. Разом із тим контекст значення не вичерпується соціальністю. Його онтологія містить твердження, що значення «дозволяе бути». Такий «дозвіл» для сущого відкрити свою сутність є унікальною рисою людського буття. I звідси слідує висновок, що сама людина є сутністю, яка інтерпретує буття, дозволяє речі здійснити своє значення, або призначення. Так реалізується екзистенціал свободи, що потребує не тільки відповідальності, але й рішучості. М. Сеол [11] пов'язує гайдеггеріанське розуміння свободи із рішучістю запиту про власну сутність. Автор вбачає в такому принципі два рівні аналітики: вихідне саморозуміння на рівні екзистенції як невизначеність чистої волі, або чистої феноменальності; та практичне саморозуміння на раціональному рівні, тобто рівні моралі. Імперативні формули моралі не суперечать фундаментальній онтології, а формалізують її зміст та унаочнюють дієвість в соціальному контексті.

Проблема пошуку себе через інтерпретацію світу у філософіï Гайдеггера є центральною. Із цією думкою солідарний Л. Одісеос [12], який вважає, що наскрізним питанням гайдеггерівської філософії є питання самоідентифікації. Критична приналежність до спільноти є різновидом міметичної діяльності, що здійснюється за допомогою традицій певної спільноти людей. Відоме скептичне ставлення Гайдеггера до спільноти та будьяких проявів її уніфікуючого впливу. Проте саме в межах конструкції акумульованих спільнотою технік інтерпретації є можливою процедура ідентифікації та самоідентифікації зокрема. Цю по- зицію поділяє професор Нордського університету Дж. Н. МакГурік [13]. Він також ставить питання про значення рішучості та ідентифікації в контексті нормативної раціональності. Автор впевнений, що екзистенціальне обгрунтування раціонального життя є необхідним як у соціальному, так і в індивідуальному існуванні. Цей механізм є прагненням людини до самовиправдання, до утвердження власної сутності в горизонті світобудови.

Примат абстракції на екзистенцією Гайдеггер називає «Ман». Як буддистська Майя, що приховує справжню сутність речей, «Ман» $\mathrm{\epsilon}$ комфортним осередком безликості: «Ман має власний спосіб буття (zu Zein)... Поступливість, звичайність, нівеляція конституюють як спосіб буття Ман те, що ми називаємо «громадськістю» [9, с. 127]. Громадськість у даному трактуванні означає об’єктивізацію через відчуження, ескапізм у фроммівській концептуалізації. Фактично така інтерпретація цього терміна є протилежною змісту поняття соціальності. Якщо соціальність атрибутивна потреба в Іншому як реалізація трансцендентальної здатності самоідентифікації, то громадськість у Гайдеггера - зворотній рух, відмова від власної сутності на користь абстрактних суспільних стереотипів. Головним рушієм ствердження громадськості є адаптація, резюмує автор. Проте цей механізм властивий тваринам, у яких існування та сутність взаємно визначені. Свобода людини означає не стільки довільність активності, скільки більший та різноманітніший інструментарій переживання і розуміння сущого.

Основні осі координат, що визначають феномен екзистенції, - це свобода і доля. Не простір і час як вихідні детермінанти позиціювання у світі, а суб'єктивне переживання своєї позиції в світі та розуміння світу - такою є семантика та синтаксис екзистенції на противагу категоріальному мисленню суб'єкт-об'єктних опозицій. Отже, екзистенція $€$ існуванням, що з необхідністю передбачає інтерпретаційні практики. Іншими словами, природа людини - це культура, а культура - сенс та квінтесенція природи, іï динаміка і логіка, причина та мета. Тобто природа та культура не протилежні, а взаємообумовлені феномени в єдиній системі фундаментальної онтології. За подібною логікою Гайдеггер руйнує, або піддає деструкції, ще одне усталене твердження: природа - це царина необхідності, культура - це простір свободи. Такий поділ є умовним, штучним. В єдиному світі, що здійснюється в часовому множинному вираженні, можливість як така є фундаментальною предикацією сущого. Відповідно, модуси необхідності та свободи, або можливості, властиві темпоральним визначенням, а не різним категоріям сущого.

Проблема полягає в іншому. I Гайдеггер чи не найперший $з$ тих, хто грунтовно і аргументова- 
но визначив фундаментальні проблеми сучасної культури. Якщо говорити про індивідуальноперсоніфікований вимір екзистенції, то свобода передбачає бажання, або потребу моральності: совісті, провини, турботи в цілому. Проте де-персоніфікований модус екзистенційного буття громадськості продукує вироджені форми моральності, цінності та культури: пліткування, допитливість, двузначність - всі ці завіси повсякденності, що руйнують сутність екзистенції та спотворюють зміст і призначення культури.

Парадоксальним видається твердження Гайдеггера, що цілісність екзистенції надає плинність часу. Дійсно, традиційно розуміння часу досягається шляхом його дискретності. Гайдеггер спростовує цю традицію, апелюючи до визначення екзистенції як буття-до-смерті. Така ментальна, усвідомлена цілісність пролонгованого в часі процесу (тобто життя), що містить різні режими темпоральності та передбачає модус майбутнього як потенційного та нереалізованого, але визначального та конститутивного, і є головною інтуїцією присутності людини в світі. У цьому і полягає трансцендентність екзистенції: як барон Мюнхгаузен, «витягувати» себе до спроектованих сценаріїв бажаного майбутнього, бажаних моделей себе та свого існування. I непересічну роль в цьому процесі відіграє культура як онтологія значеннєвого запиту, а не громадськість вироджених форм культури.

Ірунтовна робота Г. Шуфрейдера [14] з аналітики культурфілософських рефлексій М. Гайдеггера також фіксує розбіжність між соціальним як буденним та особистісним як екзистенційним рівнем існування. Проте в такій диференціації слід уникати категоричних оціночних суджень. На його думку, соціум є унаочненим втіленням історії, в межах якого визначено їі, історії, телеологію, праксеологію та аксіологію. Буттєвість людини не є константною, сталою. Навпаки, їі сутність процесуально-герменевтична: «Передбачаючи, ми можемо сказати, що, якщо це означає, за словами Гайдеггера, бути людиною, тобто бути «Dasein», це бути «місцем для не-приховання буття», то це визначення Поліс оголошує, що ми покликані до справжньої спільноти своєю суттєвою потребою оволодіти розкриттям буття, створити «місце» для його «відкриття», оскільки така майстерність, як трансформація в історію, вимагає центру для не-приховання, який може відбуватися лише колективно. Позначаючи поліс як «місце історії», Гайдеггер не просто посилається на місце, де Dasein є настільки історичним, але, як Da-sein, на ту колективну подію, яка є місцем для неприхованості бути історією» [14, с. 168]. Іншими словами, вплив соціуму на особу є комплексним, а не суто негативним та деструктивним. Подібні висновки та оцінки неправомірні.
Фундаментальний екзистенціал свободи втілює можливість для людини здійснювати те, в чому вона вбачає істину та сенс: «Таким чином, у загальновідомому прикладі «перемикання» 3 шестерні на об’єкт така зміна феноменологічної присутності істоти, яка відбувається, скажімо, я раптом звертаю вашу увагу на стілець, на якому ви знаходитесь сидячи або молоток, яким ви користуєтесь перервами, урок, який ми повинні вивчити в будь-якому випадку, полягає в тому, що відмінність між «технічністю» $\mathrm{i}$ «об’єктивністю», як різними режимами феноменальності явищ, не може бути зарахована в термінах будь-якої розбіжності в «вертикальних" або емпіричних особливостях істот, про які йдеться, але вимагає аналізу різних «онтологічних» позицій, на які люди здатні співвідноситися $з$ тією самою істотою; Аналіз, здійснений у SZ за допомогою виділення дивного та унікального чинника, він називає наше "розуміння буття», яке обумовлює нашу зустріч із істотами та є самою природою людини як Dasein: трансцендентною основою феноменальності явищ» [14, с. 170]. Важливим є той факт, що наявність свободи не означає волюнтаризму, анархї̈ або хаосу в системі фундаментальної онтології. Йдеться про горизонт людської життєдіяльності, в якому справжні смисли та цінності можливо замінити їх штучною імітацією. Проте такі довільні акти самоідентифікації людини трансформують виключно соціально-громадський вимір буттєвості, але не фундаментальний.

Тимчасовість людського існування, так само як і спроби формалізації та об’єктивації цієї плинності, є потенцією розуміння та визначення, але не вичерпує своєю операціональністю онтологічної повноти. Г. Шуфрейдер таку диференціацію верифікує таким чином: «Ми також повинні знати, що Гайдеггер розглядає феноменологічно «істину» та «схожість» як онтологічне розрізнення, як різницю передачі / об’єкта, відображаючи два різні способи, якими може представити себе одна і та сама істота. «Думки» «багатьох» залишаються пов' язаними з doxa, уявленням істот як подоби, на відміну від прихильності ранніх мислителів до alethei, дозволяючи істотам проявляти себе як істоти, якими вони є. Отже, історія насправді розглядається як поточна боротьба за встановлення тієї істини буття, яка поверне істот від їх втрати в подобі і звільнить їх за той «променистий вигляд», який належить до їх «само-виникнення»; Думка з точки зору спадщини, яка сама встановила колективно розгорнуту місію збереження явищ у «доказах» їх буття. Але активізація історії в інституті колективної темпоральності, що належить до живої традиції, не лише передбачає, що історичні особи вирішують та бажають брати участь у конкурсі проти приховування, але навіть тим більше, що стійкий центр власної роботи передбачає «приховану гармонію» «здатні координувати внески в їх можливому 
відношенні до історії» [14, с. 173]. Дійсно, мотиви, цілі та цінності окремих людей, як і окремих спільнот, суттево різняться. I найпевніше, саме в такому контексті діалектика єдиного та множинного, або проблема цілісності постає найбільш показово. Соціум, історія, культура є полем і результатом діяльності множини акторів, проте багатокомпонентна мозаїка вирізняється власною єдністю, специфікою та значенням. Доречно зважити на трансцендетальну природу цих феноменів: «Але загадка єдності культури полягає саме в тому, що як твір творів, колективний твір, культуру ніхто не головує. I феноменологія культури повинна бути в змозі запропонувати виклад іï єдності, яка відображає те, як вона є культурою, відбувається лише завдяки людській роботі, фактично не перебуваючи під безпосереднім контролем людини» [14, с. 180]. Парадоксальна ситуація: велич людського буття міститься у малих та простих речах: у плинності річки; дзвоні, що несеться рідною місциною; вузькій стежці, що пам'ятає множину подорожніх. Натомість дихотомічних категоріальних систем класичної метафізики, Гайдеггер розуміє час не як предикацію в ряду інших ознак, а як Своє / Інше самого Буття.

У протиріччі соціального та індивідуального вирішальною є категорія міри, дотримання якої утримує цілісність та достовірність сутності: «Тоді я думаю, що нам краще зрозуміти «історичну долю буття» у світлі феноменології історії, яка призвела до цього моменту у роботі Гайдеггера, i особливо з точки зору поточного регресивного аналізу, який прогресивно розкриває теми, які врешті-решт домінують в думках Гайдеггера про історію, коли він ставить під сумнів взаємозв'язок феноменальності, темпоральності та колективності; або, простіше кажучи, між буттям, часом і культурою» [14, с. 183]. Іншими словами, час як горизонт становлення форм об'єктивації суб'єктивності, або культури, демонструє можливості існування не-онтологічних, не-світорозмірних сутностей та феноменів. Оманливою буде філософська методологія, яка прагне віднайти беззаперечні відповіді. Плинність історії формує запит на критичне мислення та сприйняття дійсності: «Культура наявного людства є система величезної, зростаючої організаційної складності, є символічно щільна реальність. У ній, культурі, незліченна кількість відповідей, наслідків, слідів, які не підлягають суворому пізнанню, а можуть розкритися лише у свідомості, що розуміє і запитує. Гуссерліанська теза про інтенціональність свідомості, iï спрямованість на дещо стає у Гайдеггера набагато глибшою тезою про запитування» $[15$, с. 10]. Можливо, причиною сучасної світоглядної кризи, так само як і кризи культури, є надлишок готових відповідей щодо питань, які втратили свою актуальність. Можливо, саме какофонія готових сце- наріїв гідного людського життя в його змістовних та функціональних конфігураціях призводить до бездумності та бездушності сучасної доби.

М. Гайдеггер пропонуе іншу стратагему для людського існування, яка поєднує голос означення і тишу сприйняття, схематизм соціальності та унікальність суб'єктивності: «Справжня сутність речі, зчеплена мовою, ім'ям, струмує в тиші. Ця тиша прихована в глибинах онтології, так би мовити, «під культурою», бо символіка культури є вже озвучування, що заглушує німоту та аутентичність першоістіни. Втім, будь-який діалог зовсім не зводиться до бадьорої схемою «питання - відповідь»; він - у зіткненні питань, «модусів запитування», що взаємно стимулюють один одного і утримують в неможливості отримання голого факту вічної напруженості буття» $[16$, с. 10]». I в цьому полягає специфіка феноменологічного дискурсу культури: дослідити універсальність принципів ї̈ конструкції через дескриптивно-герменевтичні практики взаємодії зі світом в широкому розумінні: «Є принципова різниця між сутністю культури і проявом цієї сутності. Якщо останні потребують антропологічного опису, що виводить на побудову морфології культури, то сутнісний аналіз - справа цілком філософського дискурсу, що охоплює екзистенціальний, трансцендентальний і герменевтичний рівні буття-в-світі. Культура як людський світ глибоко онтологічна; вона - не «форма», і навіть не «спосіб» буття, а саме буття. Глибина гайдеггерівського запитування, що виникло в «розломі» культури XX століття і пробивається крізь всілякі кризи, «заходи», негації та ін., - лише підтвердження буттєвості культури в її сутнісних підставах. Висловлюючись точніше, запитування Гайдеггера про Буття, про Dasein як «Буття-в-світі» є по суті тривожне нагадування про сутність культури в обезбоженому і тим самим відторгнутому від власних культурних підстав столітті» [15, с. 15].

Отже, аналізуючи культуру крізь призму екзистенції, Гайдеггер відкриває нові виміри, нові модуляції семіотичної дійсності, що позначає логіку буття-в-світі. Чисту можливість Гайдеггер ототожнює із Ніщо. Рухома просторово-часова відкритість Буття пояснюється його трансцендентальною сутністю: становлення сущого в горизонті існування штовхає сталі форми до пластичності меж актуального та повернення до витоків чистої потенції. Тому виправданим буде твердження, що феноменологія $\epsilon$ тим ефективним дослідницьким методом, якого потребує фундаментальна онтологія. Дійсно, якщо в кожному моменті існування сущого в динаміці його трансформації у вигляді спектру можливостей має місце Ніщо, то тільки феноменологічний метод $є$ тим типом філософського дискурсу, що включає в себе розуміння Сущого як цілісності, враховує конститутивні предикації процесу інтенціональності свідомості та подієвість запитування. 
Гайдеггер відмовляється від волюнтативного розмежування сутності та екзистенції, його диференціація орієнтується на модальність присутності: справжню і несправжню. Модус справжньої присутності експлікує буття, що стверджує цінність свого персоніфікованого існування у формах творення смислу та цілепокладання. Несправжня присутність є існуванням посередності, анонімності, що нівелюють самість у формах міфу та множині різних інших ідеологем соціуму. На основі темпоральної інтерпретації онтологічної структури Гайдеггер пропонує відповідну структурність трансценденції. Так, просвіт минулого актуалізує присутність та постулюе можливість запиту про сенс буття. Імманенція у світ теперішнього визначає контур взаємодії людини із сущим: речами, процесами та інституціями відповідно до соціальних, культурних та мовленнєвих норм. Вертикаль майбутнього долає замкнену, циклічну конструкцію наявного буття світового сущого до трансцендентального горизонту. Здійснити цей прорив можливо персональним, індивідуальним та унікальним способом свідомо-вольового зусилля, для реалізації якого особистісні якості формуються через соціальність взаємодії з іншими персонами. Сутність, сенс та медіатор такої взаємодії $€$ мова в її онтологічному значенні. Як універсальна сутність, мова є полем переходу можливості до здійснення, оформленості та сталості. Відомо, що універсальність мови не вичерпується множиною окремих актів мовлення, тому її онтологічна сутність переважає онтичні межі буденності.

Онтологічний вимір мови буденності зорієнтований на іменування речі відповідно до її призначення та функціоналу дієвості, мова в цьому модусі виконує суто прагматичні завдання. Мова присутності є поетикою Буття, що поєднує раціональність, уяву, пам'ять, волю та емоції в єдиний акт переживання процесуальності та статичної плинності світу. Цей різновид мови не є репрезентацією, оскільки не «замінює» світ семіотичною реальністю, і не є судженням, оскільки не містить оціночних суджень та категоричності оцінок. Її призначення полягає у виявленні конструктивних зв'язків морфології світобудови.

Висновки. Виходячи з рівня і траєкторії реалізації екзистенційної свободи, Гайдеггер вирізняє три основні типи запиту в аналітиці феноменів: природній, науковий та філософський. Горизонт повсякденності привчає людину до зручності ( «під-ручності») внутрішньо світового сущого, діяльність в такому ракурсі є автоматичною та прагматичною. Науковий рівень феноменологічної редукції передбачає цілераціональну спрямованість як аналітики предмету, так і реалізації активності відповідно до встановлених об'єктивацій. Філософська дискурсивність феноменології містить іншу темпоральну орієнтацію, що пояснюється іншим фокусом сприйняття речі: не утилітарним та не схематичним. Такий ракурс аналітики включає єдність екзистенційно-ессенціальної конструкції феномену, його справжню онтологічну вираженість. Це і є акт трансцендування за межі локальності сущого як інструменту, або способу. Іншими словами, феноменологічний метод $\epsilon$ дієвим у розкритті буттєвої сутності речі, її онтологічної істини в унікально-універсальному форматі здійснення. Тому феноменологія Гайдеггера $є$ і герменевтикою водночас, оскільки пізнання-запитування $є$ пролонгованим процесом, а не результатом дії. Цей пізнавально-ознайомчий процес є швидше інтерпретаційним, а не раціональнодескриптивним. Відповідно, у філософії Гайдеггера таким аутсайдером є поняття норми, навіть якщо йдеться про наукові та об'єктивні істини: наука є важливою для людини та її цивілізації, але не вичерпної стосовно екзистенції людського буття. На його думку, культура $є$ не просто одним із способів оформлення буттєвості, його реалізацією, а швидше самим Буттям, повнотою його вираження. На противагу буденності, що є терапією примирення з дійсністю об'єктивованих сутностей, культура є динамікою в горизонті вічності, тобто Буття. Таким чином, створюючи, або проживаючи життя в культурі, людина не змінює детермінанти визначення простору і часу, а підтримує автентичність смислової конструкції Буття.

Jimepamypa
1. Overgaard S. Heidegger's Early Critique of Husserl. International Journal of Philosophical Studies, 2003. Volume 11, Issue 2. P. 157-175. URL : https://doi.org/10.1080/0967255032000074163.

2. de Boer K, Howard S. A ground completely overgrown: Heidegger, Kant and the problem of metaphysics. British Journal for the History of Philosophy. 2019. Volume 27, Issue 2: Kant's Philosophical Method: Receptions and Transformations. Guest Editor: Gabriele Gava. P. 358-377. URL : https://doi.org/10.1080/096087 88.2018.1450218.

3. Karilemla S. Heidegger's Contrasting Notion of Worldview in the Early, Middle, and Later Writings. The Humanistic Psychologist, 2015. Volume 43, Issue 3. P. 250-266. URL : https://doi.org/10.1080/08873267.201 5.1047020 .

4. Moyle T. Heidegger's Transcendental Empiricism. International Journal of Philosophical Studies, 2017. Volume 25, Issue 2. P. 227-248. URL : https://doi.org/10.1080/09672559.2016.1237533.

5. Ni L. The Phenomenological-Ontological Dimension of Philosophy of History: The Problem of History in Husserl and Heidegger. Comparative and Continental Philosophy, 2018. Volume 10, Issue 1: Current Husserl research in the chinese language. P. 7-20. URL : https://doi.org/10.1080/ 17570638.2018.1440496.

6. Casati F. Heidegger and the contradiction of Being: a dialetheic interpretation of the late Heidegger. British Journal for the History of Philosophy. 2019. Volume 27, 
Issue 5. P. 1002-1024. URL : https://doi.org/10.1080/09 608788.2018.1536030.

7. Nielsen K. Aspects of a Practical Understanding: Heidegger at the workplace. Scandinavian Journal of Educational Research, 2007. Volume 51, Issue 5. P. 455470. URL : https://doi.org/10.1080/00313830701576557.

8. Winkler R. Heidegger and the Question of Man's Poverty in World. International Journal of Philosophical Studies, 2007. Volume 15, Issue 4. P. 521-539. URL : https://doi.org/10.1080/09672550701654933.

9. Хайдеггер М. Бытие и время. / пер. с нем. В.В. Бибихина. Москва : Акад. проект, 2015. 447 с.

10. Knowles Ch. Heidegger and the source of meaning. South African Journal of Philosophy, 2013. Volume 32, Issue 4. P. 327-338. URL : https://doi.org/10.1080/0258 0136.2013.865101.

11. Seol M. Ethical Lessons from Heidegger's Phenomenological Reading of Kant's Practical Philosophy: Heideggerian Revision of Kant's Justification of Morality. Journal of the British Society for Phenomenology, 2020. Volume 51, Issue 1. P. 1-17. URL : https://doi.org/10.108 0/00071773.2019.1647609.

12. Odysseos L. Constituting community: Heidegger, mimesis and critical belonging. Critical Review of International Social and Political Philosophy, 2009. Volume 12, Issue 1. P. 37-61. URL : https://doi.org/10.1080/13698230902738528.

13. McGuirk J. N. Husserl and Heidegger on Reduction and the Question of the Existential Foundations of Rational Life. International Journal of Philosophical Studies. 2010. Volume 18, Issue 1. P. 31-56. URL : https://doi.org/10.1080/09672550903493551.

14. Schufreider G. Heidegger's Contribution to a Phenomenology of Culture. Journal of the British Society for Phenomenology, 1986. Volume 17, Issue 2. P. 166-185. URL: https://doi.org/10.1080/00071773.1986.11007760.

15. Суханцева В.К. Мартин Хайдеггер вопрошающий о культуре. 2001. Філософські дослідження. Збірник наукових праць Східноукраїнського національного університету. Випуск 2. Луганськ, 2001. С. 7-15.

16. Суханцева В. К. Хайдеггер: к онтологии обыденности. Філософські дослідження. Випуск 4. Луганськ, 2003. C. $7-15$.

\section{Анотація}

Яиенко О. Д. Феноменологія та метафізика культури М. Гайдеггера. - Стаття.

У статті обгрунтовано визнання феноменологічного методу як ефективного та доцільного в аналітиці персонального екзистенційного досвіду та його культуротворчих передумов. Показано, що сама людина є сутністю, яка інтерпретує буття, дозволяє речі здійснити своє значення або призначення; а проблема пошуку себе через інтерпретацію світу у філософії Гайдеггера є центральною. Доведено, що природа людини - це культура, а культура - сенс та квінтесенція природи, ії динаміка і логіка, причина та мета. Важливим є той факт, що наявність свободи не означає волюнтаризму, анархії або хаосу в системі фундаментальної онтології. Йдеться про горизонт людської життєдіяльності, в якому справжні смисли та цінності можливо замінити їх штучною імітацією. Проте такі довільні акти самоідентифікації людини трансформують виключно соціально-громадський вимір буттєвості, але не фундаментальний. Звідси слідує висновок, що час як горизонт становлення форм об'єктивації суб'єктивності або культури демонструє можливості існування не-онтологічних, не-світорозмірних сутностей та феноменів. Для розв'язання цієї проблеми Гайдеггер пропонує іншу стратагему людського існування, яка поєднує голос означення і тишу сприйняття, схематизм соціальності та унікальність суб'єктивності. Такий плюралізм світоглядних орієнтацій та способів самовизначення пояснюється принциповою диференціацією мотивацій та прагнень людини: природний погляд, що прагне до зручності; науковий підхід об'єктивації світу та філософський, або фундаментальний, що має за мету розкрити ессенціальну конструкцію феномену. Відповідно з переконанням М. Гайдеггера, культура є динамікою людського життя в горизонті вічності, незмінних онтологічних смислів та цінностей, Буття іншими словами. Відповідно, створюючи, або проживаючи життя в культурі, людина не змінюе детермінанти визначення простору і часу, а підтримує автентичність смислової конструкції онтології.

Ключові слова: культура, суб'єктивність, соціальність, час, простір, екзистенція.

\section{Summary}

Yatsenko O. D. Phenomenology and metaphysics of culture of M. Heidegger. - Article.

The article substantiates the recognition of the phenomenological method as effective and expedient in the analytics of personal existential experience and its cultural prerequisites. It is shown that human is an entity that interprets being, allows things to fulfill their meaning, or pre-purpose; and the problem of finding oneself through the interpretation of the world is central in Heidegger's philosophy. It has been proved that human nature is culture, and culture is the meaning and quintessence of nature, its dynamics and logic, reason and purpose. An important fact is that the presence of freedom does not mean voluntarism, anarchy or chaos in the system of fundamental ontology. We are talking about the horizon of human life, in which real meanings and values can be replaced by artificial imitation. However, such arbitrary acts of human self-identification transform exclusively the socio-social dimension of beingness, but not the fundamental level. Hence, it follows that time, as the horizon of the becoming of forms of objectification of subjectivity, or culture, demonstrates the possibility of the existence of non-ontological, nonworld-sized entities and phenomena. To solve this problem, Heidegger proposes another stratagem of human existence, which combines the voice of definition and the silence of perception, the schematic of sociality and the uniqueness of subjectivity. Such a pluralism of worldview orientations and methods of self-determination is explained by the fundamental differentiation of human motivation and aspirations: a natural look that strives for convenience; scientific approach to objectification of the world and philosophical, or fundamental, the purpose of which is to reveal the essential construction of the phenomenon. According to M. Heidegger's convictions, culture is the dynamics of human life in the horizon of eternity, unchanging ontological meanings and values, Being in other words. So, creating or living in culture, a person does not change the determinants of the definition of space and time, but maintains the authenticity of the semantic construction of the ontology.

Key words: culture, subjectivity, sociality, time, space, existence. 